\title{
LE MIROIR BRISÉ: REASSESSING THE OCCUPATION (1940-44) IN NOVELS BY MODIANO, ASSOULINE AND ROZIER
}

\author{
URSULA HENNIGFELD \\ Heinrich-Heine-Universität Düsseldorf \\ hennigfeld@phil-fak.uni-duesseldorf.de
}

\begin{abstract}
Within French post-war society, the reassessment of the Second World War and the French collaboration with the national socialist occupants started comparatively late. According to French historiographer Henry Rousso, France suffered from 'Vichy-Syndrome' until the 1970s, when the suppressed past surged and brought about an obsessive focus on the period of the Occupation, that France hasn't overcome until this day (Rousso/Conan 2013). Since the mid1970s, the period of the Occupation has also increasingly been made a topic of fictional literature. Especially around the turn of the millennium is when many novels are published that discuss the time of the German occupation in France (1940-44). This article analyzes three novels that deconstruct the Gaullist myth of the France résistante and turn against the metaphor of the années noires. The novels Dora Bruder (Patrick Modiano, 1997), La cliente (Pierre Assouline, 1998) and Un amour sans résistance (Gilles Rozier, 2003) make the gaps in the official discourse of memory visible and highlight the shades of gray that lie between resistance and collaboration.
\end{abstract}

KEYWORDS: les années noires, l’Occupation, le miroir brisé, Patrick Modiano, Pierre Assouline, Gilles Rozier, Henry Rousso.

Within French post-war society, the Second World War and the French collaboration with the national socialist occupants were reassessed comparatively late. According to French historiographer Henry Rousso, France suffered from 'Vichy-Syndrome' until the 1970s, when the suppressed past surged and brought about an obsessive focus on the period of the Occupation, that France hasn't overcome until this day (Rousso/Conan 2013).

Since the mid-1970s, the period of the Occupation has also increasingly been made a topic of fictional literature (excluding a few earlier exceptions). ${ }^{1}$ Especially around the turn of the millennium is when many novels are

1 An incomplete list includes novels such as Le silence de la mer (1942, Vercors, i.e. Jean Marcel Bruller), Les Forêts de la nuit (1947, Jean-Louis Curtis), the autobiographical report L'espèce humaine (1947, Robert Antelme), La place de l'Étoile (1968, Patrick Modiano), Les lauriers du lac de Constance (1974, Marie Chaix), Un sac de billes (1976, Joseph Joffo), La biciclette bleue (1981, Régine Desforges), 101, avenue Henri-Martin (1983, Régine Desforges), Le Diable en rit encore (1985, Régine Desforges), La douleur (1985, Marguerite Duras), Quoi de neuf sur la guerre? (1993, Robert Bober). An overview can be found in Kohut (1982-84), Literatur der Résistance und Kollaboration in Frankreich. 
published that discuss the time of the German occupation in France (1940-44). ${ }^{2}$ Their focus varies: On the one hand, they pose ethical questions, e.g. whether one shall risk one's life while showing resistance or whether one should collaborate. But the novels also discuss how strictly resistance and collaboration can be distinguished from one another. Furthermore, many texts discuss the meta-literary question whether literature can function as a medium of (cultural) memory, especially if it can compensate for the death of the last eyewitnesses. It is strikingly noticeable that the novels are frequently written from the perspective of children who witness the war and occupation. ${ }^{3}$

The first part of this article will briefly summarize the phases of French politics of memory and the reassessment of the so-called années noires in French historiography (I.). In the second part, I will analyze three novels which deconstruct the Gaullist myth of the France résistante and turn against the metaphor of the années noires by making the gaps (Fr. les blancs) and absent victim groups of the official discourse visible and by highlighting the shades of gray that lie between resistance and collaboration. I will illustrate this with Patrick Modiano's Dora Bruder (II.), Pierre Assouline's La cliente (III.) and Gilles Rozier's Un amour sans résistance (IV.).

\section{The OcCupation (1940-44) IN French Politics of Memory AND HISTORIOGRAPHY}

Olivier Wieviorka judges the beginning of the German occupation in France as follows: "The defeat of June 1940 was a deeply traumatic experience for the French" (Wieviorka 1996: 117). Silke Segler-Meßner does not consider the defeat and armistice of 1940 as a trauma, instead to her the trauma is the succeeding collaboration (Segler-Meßner 2007: 184). In accordance with Jankélévich, she suggests that the majority of French citizens didn't suffer from the occupation

2 E.g. Dora Bruder (1997, Patrick Modiano), La compagnie des spectres (1997, Lydie Salvaire), La cliente (1998, Pierre Assouline), Berg et Beck (1999, Robert Bober), Le non de Klara (2002, Soazig Aaron), Sigrand et Sip'tit (2002, Jacques Lederer), Un amour sans résistance (2003, Gilles Rozier), Un secret (2004, Philippe Grimbert), L'âme au poing (2004, Patrick Rotman), Lutétia (2005, Pierre Assouline), Elle s'appelait Sarah (2006, Tatiana de Rosnay), Les enfants de la liberté (2007, Marc Levy). During this time period the Suite française (2004, Irène Némirovsky), which had already been written in 1942, was posthumously published, such as Hélène Berr's diary of the years 1942-44 (Journal, published in 2008). Further novels include Les bienveillantes (2006, Jonathan Littell) or $\mathrm{HHhH}$ (2010, Laurent Binet), which have caused public debates. Concerning the Occupation in contemporary crime fiction cf. Müller/Ruoff 2008 and in contemporary drama cf. Felbeck 2008.

3 E.g. Un sac de billes, Quoi de neuf sur la guerre, La compagnie des spectres, Sigrand et Sip'tit, Un secret, Les enfants de la liberté. 
but rather tolerated it. ${ }^{4}$ Olivier Wieviorka gives the following summary of the way in which the French population reacted to the NS-Occupation:

In conclusion it can be said that the German occupation was in principle rejected by the French population. Only a handful hoped for collaboration - but the enemy turned down their offer. Large numbers of Frenchmen accepted the occupation as reality, however, and adopted an attitude based on a willingness to compromise. [...] Some measures were considered to be barbaric, as for instance the execution of hostages or the introduction of the Yellow Star. Such actions shocked and swayed public opinion, but they did not always induce or deter individual commitment to the Résistance, nor did forecasts concerning a German or Allied victory. (Wieviorka 1996: 129)

To this day, judging the years 1940-44 is risky and controversial. ${ }^{5}$ Directly after World War Two, Charles de Gaulle spread the myth of a heroic nation made of resistance fighters, in order to restore national unity (Segler-Meßner 2007: 184). From the German perspective, this myth of heroic resistance shared by Gaullists and Communists alike - is often being commented on with certain contempt and the latent feeling of superiority. ${ }^{6}$ However, Frank-Rutger Hausmann rightly warns about some kind of arrogance or moralism from the German side: In a one-sided manner, collaboration is frequently seen as a French matter, whereas the German counterpart is disregarded (Hausmann 2005: 113). ${ }^{7}$

Ahlrich Meyer's theses point towards a similar direction. He defines the historiography of the early FRG as apologetic, since it tried to maintain the image of a 'correct' German domination of the West ("'korrekte[..]' deutsche[..] Herrschaft im Westen”, Meyer 2000:5). Meyer illustrates this using standard historiographical reference works by Eberhard Jäckel (Frankreich in Hitlers Europa, 1966) and Hans Umbreit (Der Militärbefehlshaber in Frankreich, 1968). In spite of their abundance, both works ignore the sources concerning the

4 "Im Schatten der rassistischen und politischen Verfolgung der Juden und der résistants konnten die französischen Bürger unbehelligt ihre Spaziergänge im Park fortsetzen und das kulturelle Leben genießen." (Segler-Meßner 2007: 183).

${ }^{5}$ According to Segler-Meßner (2007: 197), since the year 2000 there has truly been a dispute ("Meinungskrieg") concerning the interpretation of the occupation.

${ }^{6}$ Cf. the chapter 'The French were all Résistance-fighters' ("Alle Franzosen waren in der Résistance") in Alles Mythos. 16 populäre Irrtümer über Frankreich (Nestmeyer 2014: 111-124). Other "myth"-chapters in this book are: The French are all Gauls, All Frenchmen are Brothers, Charlemagne is French, The Tour de France is a Bicycle Race, Jeanne d'Arc is France's Savoir, The Rhine is France's 'Natural' Border, Napoleon is Immortal, France is Germany's Archenemy, The French Love the Revolution, Paris is (just) a City, The French Cuisine has Always been Superior to the German one, France is a Great Power.

7 In his article, Hausmann analyzes the Europäische Schriftsteller-Vereinigung (ESV), which was founded by Goebbels in 1941. In 1941, the ESV organized a poetry conference with the participation of 200 German and over 50 European writers. Hausmann indicates that the participants of this conference accepted fascism as a state doctrine, the Gleichschaltung, the expulsion and persecution of their Jewish colleagues as well as indoctrination. The participants let themselves be turned into propagandists of the NS European policy (Hausmann 2005: 114). 
persecution and deportation of the Jews and they attest that German occupants have conducted a 'clean administrative work' ("saubere Verwaltungsarbeit", Meyer 2000: 5). Meyer states that the early historiography in the FRG was dominated by the figure of the 'perpetrator-historian' ("Täter-Historiker[...]", ibid.: 6). Until the end of the 1960s, the FRG-historiography failed to perceivably break with the NS-Generation (ibid.: 6). ${ }^{8}$ Against this background, the theses stating that French historiography was 'delayed' in coming to terms with the years 1940-44 ought to be treated with caution.

The first monographs on the Occupation were published in Englishspeaking countries. Some examples of these monographs are Stanley Hoffmann's article on the state collaboration of the Vichy-Regime (Hoffmann 1968), the pioneering work by Robert O. Paxton (Paxton 1972) that has also been translated into French, or Paxton/Marrus's study on the role which the VichyRegime played during the persecution of the Jews (Paxton/Marrus 1981). Serge Klarsfeld's two-volume monograph Le role de Vichy dans la solution finale de la question juive en France can also be considered as groundbreaking (Klarsfeld 1983, 1985).

Credit must be given to Henry Rousso for conducting broad research on the official French politics of memory. He divides the French post-war era and its culture of memory into two main periods: the years 1944-1970 and the years 1970-2000 (Rousso 2004). In their monograph Vichy, un passé qui ne passe pas, Rousso/Conan distinguish even more precisely between four phases: the years 1944-54 (phase de deuil), 1954-71 (phase de refoulement), 1971-74 (le miroir brisé) and the years after the mid-70s (phase obsessionnelle). ${ }^{9}$ In the immediate post-war years, De Gaulle's public speeches give the impression that the French Republic has never ceased to exist and that the Vichy-Regime's collaboration was just a brief historic digression (Rousso 2004, Segler-Meßner 2007: 108). To fortify this myth, Jewish victims, as well as prisoners of war and forced laborers, were excluded from the official politics of remembrance. Debates about shorn women and some trials of social 'cleansing' distract from the problems of fascist ideology and anti-Semitism in France. Flags, parades and monuments establish a homogenous national memory of resistance (Lagrou 2002). ${ }^{10}$ Official

8 The one-sided view on the German occupation of France has not yet been fully rectified, writes Meyer in 2000. There is still no German monograph that studies the persecution of Jews, economical plundering and strategies of repression by the Nazis in France (Meyer 2000: 8). Concerning the economic aspects of German occupation, cf. Dard/Dumas/Marcot 2000 or Jungius 2008.

${ }_{9}$ Cf. Rousso/Conan 2013: 21f. and Albersmeier 1995.

${ }^{10}$ According to Lagrou, during the 1940s and 1950s, the memory of the concentration camps is still comparatively present. To illustrate this, he mentions David Rousset's L'univers concentrationnaire (1946). However, the 1950s and 1960s mark the beginning of the systematic exclusion of forced laborers and prisoners of war from the collective memory, in favor of the Résistance-fighters who are celebrated as martyrs and heroes of national resistance (Lagrou 2002: 168). - Segler-Meßner reaches a similar result. She highlights that the Communists also 
commemorative events erase distinctions between different victim groups and privilege the ideal victim of the deported resistance-fighter (Rousso 2004: 233). The examples, which Rousso mentions, are monuments such as the Mémorial de la France combattante (1958) on Mont-Valerién, the Mémorial national de la Déportation (1960) in the camp Struthof near Strasbourg or the Mémorial des Martyrs de la Déportation (1962) on the Île-de-la-Cité.

The film Nuit et brouillard by Alain Resnais, based on the script written by the Résistance-fighter and Mauthausen-survivor Jean Cayrol, is censored in 1955 because it doesn't agree with the official politics of memory: Resnais's film shows a French gendarme working as a guard in the Pithiviers camp. Rousso sees the monument for the children of Izieu as another problematic example of this phase in the national culture of memory, because it doesn't mention the reason for them having been deported, which is that they were Jews. Instead, under De Gaulle, the commemoration of the Résistance is converted into the pillar of a new national unity. The decision to move Jean Moulin's mortal remains into the Panthéon was also part of these politics of memory.

According to Rousso, a transformation of the official politics of memory was caused by the "crisis of 1968", De Gaulle's resignation, the foundation of Israel and the growing immigration of Algerian Jews to France. As a reference for this change in the official culture of memory, Rousso mentions the publications by historian Zeev Sternhell on French fascism, the first novels by Patrick Modiano (e.g. La Place de l'Étoile, 1968)11 and the film Le Chagrin et la Pitié (Marcel Ophüls 1971), which thematizes the deportations of French Jews into camps of mass-extinction. The film is screened in the cinemas in the very year that Georges Pompidou causes a scandal by pronouncing a secret pardon for Paul Touvier.12 Rousso uses the metaphor of "le 'miroir brisé'" (Rousso/Conan 2013: 22) to describe the early 70s, which I will return to while analyzing the novels.

1979 can also be considered a turning point, because the Vichy-files are released and the American TV miniseries Holocaust is being screened in France. In 1985, Claude Lanzmann's Shoah enters the cinemas and in the following years, great trials against war criminals commence in France (1987 Klaus Barbie,

used the myth of France résistante for their purpose. By the end of the 1940s, states SeglerMeßner, the interest in witness reports by deported people ceased (Segler-Meßner 2007: 194).

${ }^{11}$ Cf. the article Topographie et histoire : Paris et l'Occupation dans l'œuvre de Patrick Modiano, Gerhardi 1995.

${ }^{12}$ In his article "Vichy" in Pierre Nora's Les lieux de mémoire, Philippe Burrin also dates the change in the official politics of memory to after 1970 and considers Ophüls's film Le Chagrin et la Pitié as paradigmatic for this change (Burrin 1992: 339). According to Stefan Martens, the national myth already starts to crumble by the end of the 1960s (Martens 1992: 185). Cf. Martens 2000. 
1994 Paul Touvier, 1998 Maurice Papon; René Bousquet is murdered shortly before his trial). ${ }^{13}$

The year 1990 is also relevant, because it marks the $50^{\text {th }}$ anniversary of the beginning of the so-called années noires. Martens describes the conference organized on that occasion by the Institut d'Histoire du Temps présent (IHTP) and the following publications as milestones in the research on Vichy. Martens's diagnosis in 1992 is that France must bid farewell to a historical perception that was formed in 1944 and is putting the country at risk. The only way for France to surpass 'Vichy-Syndrome', which was diagnosed by Henry Rousso, is to accept that Vichy was not an externally controlled temporary 'system failure' ("Betriebsunfall", Martens 1992: 205). Since then, an extensive amount of historiographic research literature on Vichy has been published. ${ }^{14}$

In 1993, François Mitterand establishes a national memorial day for the victims of anti-Semitism. This day is placed on July 16, in commemoration of the Rafle du Vélodrome d'Hiver on July 16/17, 1942. One year later, Mitterand's own connections to the Vichy-Regime are revealed, causing a scandal. Jacques Chirac's speech on July 16, 1995, can be considered a milestone, because he is the first to admit the shared responsibility of the Vichy-government for the deportations of French Jews:

${ }^{13}$ Klaus Barbie, the "butcher of Lyon", was the head of the Gestapo in Lyon. Shortly before the end of the war, he went into hiding in Germany and was sentenced to death in absentia. He was recruited by the US Secret Service, but he was traced by Beate and Serge Klarsfeld in Bolivia where he had been living under the name of Klaus Altmann. He was extradited to France in 1993, convicted in 1987 and died in prison in 1991 (cf. Hammerschmidt 2014 and the documentary Hôtel Terminus, Ophüls 1988). Paul Touvier was a member of the militia of the Vichy-Regime and as one of Barbie's employees, he administered the deportations of Jews and the persecution of the Résistance. In September of 1944, he went into hiding and was sentenced to death in absentia. He was arrested while attempting to rob a bakery in 1947, fled, hid in churches and monasteries and was pardoned by Pompidou in 1971. Two years later, he was accused of crimes against humanity, but wasn't caught until 1989 in a monastery near Nice. He was able to live in the underground for years because right-wing Catholic priests gave him shelter. Touvier died in prison in 1996. Maurice Papon, the Prefect of Bordeaux, was responsible for the deportations to Drancy. After the Second World War, he used a false identification, stating to be a Résistance-fighter. He worked in successful careers in Paris, Algeria and Morocco and even made it to the Prefect of Police in Paris. In 1997, he was accused of crimes against humanity in what would be the longest trial in French history, and he was convicted in 1999. Nevertheless, three years later he was released because of illness and died in 2007. René Bousquet was the head of the Vichy Police and was responsible for the deportations (cf. Klarsfeld 1989: 592f.).

${ }^{14}$ Cf. Azéma 1992, Azéma/Bédarida 2000, Baruch 1996, Laborie 2001, Rousso 2001, as well as the Dictionnaire historique de la France sous l'Occupation (Cointet 2000), the Dictionnaire historique de la Résistance (Marcot/Leroux/Levisse-Touzé 2006) and the Dictionnaire commenté de la collaboration française (Randa 1997). - Other topics that have been analyzed include Femmes sous l'occupation (Bertin 1994), La vie musicale sous Vichy (Chimenès 2001), Artists under Vichy (Cone 1992), Sartre, Vichy et les intellectuels (Galster 2001), La vie quotidienne des écrivains et des artistes sous l'Occupation 1940-1944 (Ragache 1988), Les évêques au temps de Vichy (Clément 1999) or La guerre des écrivains (Sapiro 1999). 
[C]es heures noires souillent à jamais notre histoire, et sont une injure à notre passé et à nos traditions. Oui, la folie criminelle de l'occupant a été secondée par des Français, par l'Etat français. [...] La France, patrie des Lumières et des Droits de l'Homme, terre d'accueil et d'asile, la France, ce jour-là, accomplissait l'irréparable. Manquant à sa parole, elle livrait ses protégés à leurs bourreaux. [...] Nous conservons à leur égard une dette imprescriptible. ${ }^{15}$

Parallel to the inauguration of the Mémorial de la Shoah in Paris (2004), schools in Paris and the entire country put up commemorative plaques with the following words (depending on the Arrondissement, the exact phrasing varies, e.g. the number of Jewish students is mentioned): “À la mémoire des élèves de cette école déportés de 1942 à 1944 parce que nés juifs, victimes innocentes de la barbarie nazie avec la complicité du gouvernement de Vichy. Ils furent exterminés dans les camps de la mort. Ne les oublions jamais."16 In German schools, comparable commemorative plaques are still an exception. The public debate in 2007, whether Guy Môquet's farewell letter should be a compulsory part of school syllabi, as wished by former president Sarkozy, shows that the period of occupation is controversial to this very day. ${ }^{17}$ Rousso/Conan (2013: 337) describe Sarkozy's presidency as a commemorative relapse into "néorésistencialisme". Concerning the French 'Vichy-Syndrome', even in 2013 they state: "La présence de ce passé est trace d'un deuil inachevé." (ibid.: 9). ${ }^{18}$

\section{2. “CETTE COUCHE ÉPAISSE D'AMNESIE": DORA BRUDER (1997)}

At the beginning of the novel, the first-person narrator encounters a missing person announcement in Paris-Soir dated December 31, 1941. The parents of fifteen-year-old Dora Bruder are searching for their missing daughter:

\footnotetext{
${ }^{15}$ Allocution de M. Jacques Chirac, Président de la République, prononcée lors des cérémonies commémorant la grande rafle des 16 et 17 juillet 1942, from http://www.jacqueschiracasso.fr/les-grands-discours-de-jacques-chirac/?post_id=2326 (Retrieved on March 1, 2018).

16 Cf. https://www.paris.fr/actualites/inauguration-du-monument-a-la-memoire-des-enfantsjuifs-5180 and https://www.google.de/url?sa=t\&rct=j\&q=\&esrc=s\&source=web\&cd=10\&ved=0ahUKEwjt-pms9_ZAhUJShQKHYZTDBkQFghwMAk\&url=http\%3A\%2F\%2Fwww.enseigner-histoireshoah.org\%2FgetMedia.aspx\%3FID\%3D205\%26D\%3Dattachment\&usg=AOvVaw1VE0oyH9Ud HMsa5EOPnbp8 (Retrieved on March 9, 2018).

17 In 2007, teachers and historians protest against converting a Communist resistance fighter into a role model. They criticized this attempt to dictate historiography. Cf. http://www.faz.net/aktuell/politik/moquets-abschiedsbrief-resistance-in-frankreichs-schulen1485787.html (Retrieved on March 9, 2018).

18 Philippe Grimbert's novel Un secret (2004) uses a psychoanalytic approach to discuss the effect that suppressed grief and silence can have on future generations. The novel Les enfants de la liberté (2007), by bestselling author Marc Levy, gives a fictional account of his father's and uncle's family history, which idealizes the Résistance.
} 
PARIS. On recherche une jeune fille, Dora Bruder, 15 ans, 1m55, visage ovale, yeux gris marron, manteau sport gris, pull-over bordeaux, jupe et chapeau bleu marine, chaussures sport marron. Adresser toutes indications à M. et Mme Bruder, 41 boulevard Ornano, Paris. (Modiano 1999: 7)

Following this advertisement, the narrator begins searching for clues and tries to reconstruct the girl's life. He finds the building in which the family had lived and is able to retrace the arrangement of the rooms in the apartment. After a few bureaucratic obstacles, he manages to determine the parents' exact birth dates and their marriage certificate. However, in the course of his research, he realizes that he is repeatedly confronted with what he calls "ce blanc, ce bloc d'inconnu et de silence" (ibid.: 28).

Bit by bit, he gathers family photographs and the register listing students' names of the boarding school to which Dora had been sent by her parents maybe in order to protect her from the raids. The narrator is able to detect the number of the compulsory Jewish registration file (Judenakte) and notices that the parents didn't register Dora with German authorities. He finds a note stating that Dora had run away from the boarding school twice. Thus, the narrator plans to fill the void between Dora's escape from boarding school on December 14, 1941 and her deportation to Auschwitz on September 18, 1942.

The text is the testimony of this search for traces. The narrator increasingly identifies himself with the young girl. He imagines her loneliness, despair and her fear of boarding school. However, in spite of his intense search, which almost turns into an obsession, he has to admit that Dora Bruder belongs to those people who have disappeared leaving hardly any trace:

Ce sont des personnes qui laissent peu de traces derrière elles. Presque des anonymes. Elles ne se détachent pas de certaines rues de Paris, de certains paysages de banlieue, où j'ai découvert, par hasard, qu'elles avaient habité. Ce que l'on sait d'elles se résume souvent à une simple adresse. Et cette précision topographique contraste avec ce que l'on ignorera pour toujours de leur vie. (ibid.: 28)

However, he hopes that the places where Dora has lived hold a miniscule trace of their resident and thus help him retrieve the young girl's story. But he notices that his project is bound to fail. He feels increasingly surrounded by the night, the unknown, oblivion and the void. The narrator feels a growing fear of not finding even the smallest hint that would help him fill the blank parts of this life story.

In the end, he has to admit that it is impossible to close the gaps in Dora Bruder's story:

Il n'y a aucune trace d'elle entre le 14 décembre 1941, jour de sa fugue, et le 17 avril 1942 où, selon la main courante, elle réintègre le domicile maternel, c'est-à-dire la chambre d'hôtel du 41 boulevard Ornano. Pendant ces quatre mois, on ignore où Dora Bruder était, ce qu'elle a fait, avec qui elle se trouvait [...] Jusqu'à ce jour, je n'ai trouvé aucun 
indice, aucun témoin qui aurait pu m'éclairer sur ses quatre mois d'absence qui restent pour nous un blanc de sa vie. (ibid.: 88f.)

It becomes apparent that the narrator can only point to the trace of an absence that cannot be changed or compensated. The novel ends with the narrator's recognition that the voids in Dora's life are the remainders of dignity and humanity that even the Nazis were not able to wrest from her:

\footnotetext{
J'ignorerai toujours à quoi elle passait ses journées, où elle se cachait, en compagnie de qui elle se trouvait pendant les mois d'hiver de sa première fugue et au cours des quelques semaines de printemps où elle s'est échappée à nouveau. C'est là son secret. Un pauvre et précieux secret que les bourreaux, les ordonnances, les autorités dites d'occupation, le Dépôt, les casernes, les camps, l'Histoire, le temps - tout ce qui vous souille et vous détruit - n'auront pas pu lui voler. (ibid.: 144f.)
}

This citation illustrates the ambivalence of "le blanc" in Modiano's text: On the one hand, it represents the absence of colors, on the other hand it metaphorically expresses a "void", "gap" or a "blank space". Modiano frequently uses the metaphors of light and darkness as structuring elements of his novel. Night and darkness symbolize oblivion and evil, whereas light serves as a metaphor for goodness, memory and writing (as an effort of remembrance). The night also represents the missing exact knowledge of historic facts, as well as the Nazi-regime, which to this very day prevents us from appropriately remembering the victims of the Shoah.

Thus, Modiano's narrator describes the aim of his novel as follows: "En écrivant ce livre, je lance des appels, comme des signaux de phare dont je doute malheureusement qu'ils puissent éclairer la nuit. Mais j'espère toujours." (ibid.: 42). Writing about the Shoah hence functions as an appeal and exemplifies the hope that the reader might also start searching for traces. Because even though a complete reconstruction isn't possible, the narrator has nevertheless found out more about Dora Bruder than what was known at the beginning of his research.

When the narrator describes his own childhood memories, he uses expressions of certainty, such as "je me souviens" (ibid.: 21, 29, 35, 41, 57, 77, 100, 132) or even "je me souviens exactement" (ibid.: 69). When he successfully finds information about Dora, he uses the phrases "j' ai retrouvé" (ibid.: 28, 43), "j'ai appris" (ibid.: 60) or "J'ai trouvé, par hasard" (ibid.: 121). However, there are also situations in which he evades possible certainties and delays the chance to learn of anything definitive. To the narrator, knowing anything for sure means losing hope and considering the worst. His fear of the irrevocable shows in sentences such as "Un jour, j'irais. Mais j'hésite. Je veux encore espérer" (ibid.: 14) or "Un jour j'irai [...], mais je crains" (ibid.: 19).

Throughout the novel, expressions of vagueness, ignorance and doubt are dominant. Modiano uses an entire compilation of phrases, " $j$ 'essaye de reconstituer" (ibid.: 23), "je suppose" (ibid.: 27, 38, 39, 83), "je me suis demandé" (ibid.: 37), "j'ignore" (ibid.: 38, 42, 59, 74, 83), "je devine à peu près" 
(ibid.: 39), "j'en doute" (ibid.: 102), "il se peut que" (ibid.: 64), "je crois" (ibid.: 64), "il est probable que" (ibid.: 107), "j'ai fini par me persuader" (ibid.: 61), "on ne saura jamais" (ibid.: 76), “il faudrait savoir si" (ibid.: 59) or "j'essaye d'imaginer" (ibid.: 45). Furthermore, his frequent use of suspension points or interrogative sentences intensifies the feeling of insecurity and doubt. ${ }^{19}$ Telling the entire story of Dora Bruder's life and the cause of her death turns out to be impossible.

The narrator feels obliged to take on this never-ending, difficult and painful work of remembering, in order to salvage Dora Bruder - who for him represents all victims of the Shoah - from collective oblivion: "Si je n'étais pas là pour l'écrire, il n'y aurait plus aucune trace de la présence de cette inconnue" (ibid.: 65). With this metatextual novel, Modiano criticizes French society for apparently consenting to collective oblivion. There are zones of concealment, suppression and oblivion, a 'thick layer of amnesia' ("une couche épaisse d'amnésie", ibid.: 131). ${ }^{20}$

After the last witnesses have died, it is literature, which has the responsibility of maintaining the memory of the Shoah. This is the only mode of salvaging victims' lives from collective amnesia. Even though the absence of the murdered Jews is irrevocable and many traces have been lost forever, we owe the victims this effort of collective memory. Modiano calls upon the reader to participate in at least making the traces of the absent murdered people visible.

Modiano had discovered the names of Dora Bruder and her parents in Serge and Beate Klarsfeld's monograph Mémorial de la déportation des juifs de France (1978). For the research on his autofictional novel, Serge Klarsfeld had given him important advice and information. After the book was published, Klarsfeld and Modiano parted ways because Klarsfeld expressed his confusion and displeasure about not having been mentioned at all. ${ }^{21}$ On June 1, 2015, the mayor of Paris, Anne Hidalgo, and Patrick Modiano inaugurated a street named after Dora Bruder in the $18^{\text {th }}$ Arrondissement in Paris, the Promenade Dora Bruder. ${ }^{22}$

\section{3. “LES ANNÉES NOIRES AVAIENT ÉTÉ GRISES": LA CLIENTE (1998)}

Similarly to Dora Bruder, La cliente is a docufictional novel. The original plan of the first-person narrator is to write a biography about a woman named 'Désiré Simon' and to find out whether this person was denounced during the

\footnotetext{
${ }^{19}$ Concerning the suspension points cf. Modiano (1999: 84f.), and for the interrogative phrases cf. ibid.: 37f.

${ }^{20}$ Cf. Böhm (2009: 103-116) and Schutz (2000: 873-897).

${ }^{21}$ Cf. http://lereseaumodiano.blogspot.de/2012/01/modiano-klarsfeld-unecorrespondance.html (Retrieved on March 9, 2018).

${ }_{22}$ Cf. http://www.lemonde.fr/culture/article/2015/06/01/a-paris-une-promenade-dora-bruderen-memoire-des-victimes-du-nazisme_4644628_3246.html (Retrieved on March 9, 2018).
} 
occupation. During his research in an archive, he encounters a file containing different denunciatory letters. He discovers that the Jewish Fechner family, to whom he has family ties, was denounced by a certain Cécile Armand-Cavelli. It turns out that the old woman owns the flower shop across from the Fechners' store. Soon, the narrator also finds her letter, dated December 8, 1941, and the response by the authorities from April 17, 1942.

First, he tells the son of the denounced family, François Fechner, about his discovery. But even after François asks him to leave the past behind, the narrator continues with his research, which becomes more and more obsessive. He tries to personally meet Madame Armand, buys flowers in her store and observes her. His actions are increasingly bold: He buys chrysanthemums and asks the old woman to deliver them to the grave of the Fechner-parents. She briefly responds: "Je les croyais morts en déportation, ceux-là." (Assouline 1998: 110). The derogatory "ceux-là" shocks the narrator who sees this as a proof for her anti-Semitic attitude. He starts sending her threatening letters and makes anonymous phone calls at night. Then, one day, he sends a friend, who is a concentration camp-survivor to the flower shop and instructs him to show the number tattooed on his arm. He even publicly denounces the woman during a bus ride; after this incident, the police order him to stop harassing Mme Armand.

Henceforth, the focus of his research lies on the officer who had filed the report. Against the officer's will, the protagonist enters his apartment. He discovers that the Germans had held Mme Armand's brother as a prisoner of war. The official had blackmailed her by stating that her brother would come free if she provided information about the Fechner family. The Jewish Fechner family had gone into hiding after they were prohibited to own a store. After Mme Armand informed the authorities about the new store and the whereabouts of the Fechners, she was forced to write the denunciatory letter. ${ }^{23}$ After the war, the authorities' letter of response is found, the woman is officially questioned, named a collaborator and her head is shorn. The entire neighborhood speaks badly of her and spreads rumors, e.g. that she is only rich because of the black market and has had intercourse with Germans. Mme Armand goes into hiding for some time and her husband continues running the shop. But she cannot live on with the humiliation and tries to commit suicide by plunging into the mirror (and her hated reflection). She is rescued, but her husband leaves her.

23 “Dès les premiers jours de 1942, l'inspecteur Chifflet s'était présenté chez Armand Fleurs dans le cadre de son enquête de voisinage. Cécile Armand-Cavelli avait répondu par la négative à toutes ses questions. [...] Chifflet lui proposa donc un marché : le retour du prisonnier de guerre en échange de sa coopération (il évitait le mot 'collaboration'). [...] Il lui avait dit qu'elle avait le choix entre sauver la vie de son frère et sauver celle des Fechner. Une fois son accord obtenu, il posa une condition supplémentaire: elle devait écrire une lettre de dénonciation localisant précisément les Fechner." (Assouline 1998: 164ff.). 
The narrator remembers having once followed Mme Armand into the church Saint-Lambert-de-Vaugirard. He returns to the church and discovers a commemorative plaque for fallen soldiers on which the name of Mme Armand's brother is engraved. The narrator realizes that Mme Armand has also been betrayed. Even though she turned the Fechners' in to the police her brother wasn't released.

Thus, the narrator has to revise his clearly negative image of Mme Armand as a perpetrator. He now finds the collaborating official to be more appalling, since he blackmailed the woman and forced her to denounce the Jews by leading her to believe she could rescue her brother. Mme Armand suffered from her own feelings of guilt, the loss of her husband, the people's gossip and social shunning, whereas the police official was never held accountable or punished for his actions. The past turns out to be more complex than the narrator had suspected, guilt and innocence cannot always be held apart. Consequently, he again calls Mme Armand and asks her for a meeting. Because she doesn't know that he wants to apologize, and only remembering him as the anonymous telephone voice, follower and accuser in the bus, she runs out of the house in panic, gets hit and killed by a bus. The narrator himself is now guilty - his reckless quest for knowledge has turned into an obsession and led to the death of another human being.

While the beginning of the novel revolved around the question of how the line between good and evil became blurred during the Occupation, the narrator's own values gradually change in the course of his research. He actually believes that his aim - to bear witness to daily evil and reassess this historic period - justifies all means. In doing so, he uses a typically terrorist rationale: "La fin justifiait les moyens. Il fallait que je sache pourquoi" (Assouline 1998 : 159). ${ }^{24}$ His plan to discover the truth, avenge the victims and single-handedly punish the perpetrators was selfish and naïve. However, in the course of his investigation and obsessive pursuit of the old lady, he has to admit that the division between perpetrators and victims is more complicated than expected:

Plus je m'enfonçais dans le maquis des archives, plus je m'apercevais que les années noires avaient été grises. Elles n'étaient qu'ambiguïté et compromis. Elles avaient la couleur du flou. L'engagement net et entier, de quelque bord qu'il fût, était l'exception et non la règle. (ibid.: 59f.)

24 The more the narrator investigates, the more difficulties he has in finding the reasons for human behavior. The other inhabitants of the neighborhood with whom he discusses the case, try to explain to him that knowledge for the pure sake of knowing is senseless: At the end of the novel, a mirror salesman named M. Ardet asks the narrator: "Maintenant, vous savez tout, vous qui brûliez de tout savoir. Mais est-ce que vous comprenez mieux pour autant?" (ibid.: 183) and François Fechner, a member of the victimized family, says: "Maintenant, tu sais tout. Tu connais les faits et les événements. À quoi bon?" (ibid.: 186). 
He eventually figures out what Hannah Arendt named the 'Banality of Evil'. ${ }^{25}$ Nevertheless, Mme Armand also fails to explain her point of view. She just screams at him, saying that things are more complex than the members of future generations can imagine. ${ }^{26}$ Therefore, cross-generational communication about the period of occupation doesn't succeed in this novel.

Assouline shows how the suppressed history of the Occupation haunts the French people to this very day:

On n'en finira jamais avec cette histoire. Elle nous hante, elle nous obsède, impossible de nous en débarrasser. Plus d'un demi-siècle que la méduse nous colle à la peau. Quand certains meurent de leurs mœurs, d'autres étouffent encore de ce passé qui ne passe pas. Après tout, à chacun ses insomnies. Les plus à plaindre ont la nostalgie de ce qu'ils n'ont même pas connu. Cet étrange spectre est l'astre noir de notre morale. Qui saura l'exorciser ? Qui... (ibid.: 11)

The narrator explicitly uses the title of the monograph by Rousso/Conan, Vichy, un passé qui ne passe pas (1994). The novel's end is similar to that of Dora Bruder: Assouline's narrator also has to admit that he didn't achieve his aim to unveil each person's experiences, motives and actions:

Une dizaine d'années ont passé. Il m'arrive souvent de penser à Cécile Armand-Cavelli. Je ne sais pas tout de son histoire. Des zones d'ombre subsistent. [...] Cette histoire me poursuit encore. Elle hante mes jours et mes nuits, moins toutefois depuis que je l'ai dévoilée. [...] Puisque j'ai fait partie de sa mort, elle fait partie de ma vie. (ibid.: 190)

This citation clearly shows that Assouline also uses the metaphor of light and darkness, which influences the historiographical discourse (les années noires) and the literary discourse about the Occupation, as seen with Dora Bruder. In the literary discourse, what Rousso/Conan have called "un enjeu de mémoire obsessionnel" (Rousso/Conan 2013: 22), appears in phrases such as "me poursuit", "Elle hante mes jours et mes nuits." It is also typical to talk about the years of German occupation as if they were a 'secret' that ought to be uncovered ("dévoilée").

\section{4. “AVAIS-JE LE CHOIX?": UN AMOUR SANS RÉSISTANCE (2003)}

Gilles Rozier's novel begins with the description of a family photo. As the narrator characterizes the relatives, it turns out that each family member represented a specific group during the Occupation. The novel can therefore be

25 "Si cela n'avait été que haineux, ce serait simple. Mais lorsque le mal s'exprimait dans toute sa banalité, lorsqu'il apparaissait profondément ordinaire, la raison déposait les armes. Car, avec l'Occupation, on n'est plus dans la politique. Pendant quatre ans, ce fut à chaque heure l'heure de vérité qui révéla la part d'humain ou d'inhumain en nous." (ibid.: 27).

26 "- Vous ne comprenez rien! cria-t-elle. Vous ne comprendrez jamais rien! [...] La vérité, personne ne peut la comprendre. Il n'y a plus personne pour l'entendre. Il n'y a jamais eu personne." (ibid.: 137). 
read allegorically: The absent father is a prisoner of war in Germany, where he works on a farm and - after the farmer is drafted to the Eastern front - gets the farmer's wife pregnant. ${ }^{27}$ One of the sisters, Isabelle, lives in the zone libre with her husband, who is from the Southwest, and their four children. ${ }^{28}$ The other sister, Anne, was married to a man who signed up for the Légion des volontaires français contre le bolchévisme (LVF), a unit of French volunteers in the Wehrmacht. After this first husband is shot by the Résistance, Anne starts a relationship with the SS-member Volker Hammerschimmel. After the Libération, Anne is raped by a neighbor and shorn for having collaborated with the enemy. ${ }^{29}$ The mother is mainly a silent and compliant follower. ${ }^{30}$

The priest of the nameless town, in which the novel is set, shows empathy for people who have committed suicide as he preaches from his pulpit, while at the same time taking part in the agitation against Jews (Rozier 2003: 75). Many of the town's inhabitants benefit from the Shoah by taking over Jewish stores (ibid.: 45). Even the children at school witness the collection and deportation of fellow Jewish schoolchildren (ibid.: 46). However, some French people show their solidarity, such as Madame Pelloux, who lets the Jew Herman rent her room even after the 'Jewish Statutes' are passed (ibid.: 79).

The novel doesn't clarify whether the narrator is a woman or a homosexual man. ${ }^{31} \mathrm{He} /$ she is married to Claude, but the name and gender of this person also remain ambivalent. It is likewise impossible to know if the narrator forms part of the resistance or the collaboration: He/she describes him/herself as a 'lukewarm patriot' who simply adjusts him/herself to the occupying forces. ${ }^{32}$ The narrator detests the German occupiers but also the French self-subjugation, which he/she sees paradigmatically incarnated by his/her sister's commitment to the SS-officer Volker. ${ }^{33} \mathrm{He} /$ she loves the German

27 "Mon père était prisonnier en Allemagne" (Rozier 2003: 12); "Mon père est resté seul à faire tourner la ferme, avec la fermière, et de fil en aiguille il a fini dans son lit" (ibid.: 96).

${ }_{28}$ “Quand le territoire national a été coupé en deux par la ligne de démarcation, elle n'en fut pas mécontente: un trait tracé en gras sur les cartes de France la séparait de nous, une frontière comme un cordon sanitaire." (ibid.: 16).

29 "son mari avait déjà été liquidé par la Résistance" (ibid.: 11), "À la Libération, un voisin a violé ma sœur Anne sous les applaudissements de tout de quartier" (ibid.: 12).

30 "une esclave courbant l'échine sous les coups de son tortionnaire" (ibid.: 14), "ma mère n'a jamais rien dit" (ibid.: 14), "Elle ne posa pas de questions" (ibid.: 151), "une machine à engloutir la réalité sans jamais la recracher" (ibid.: 151).

31 The different hints that point towards a man or a woman don't form a clear picture. The following sentence suggests that the narrator is female: "J'étais comme une chienne de chasse" (ibid.: 84). It would have been possible to use the male form (chien de chasse).

32 The narrator shares the opinion of the French majority, acceptancy and adaption, as seen in the above mentioned citation of Olivier Wieviorka. "je subissais l'interdit et m'en arrangeais." (Rozier 2003: 26); “je m’habituais à l'Occupation” (ibid.: 44), "Quant à mon patriotisme, il était comme celui de tant d'autres: mou" (ibid.).

33 “Je n'avais pas aimé leur air arrogant" (ibid.: 41), "Je n'avais pas non plus apprécié la facilité avec laquelle la France s'était glissée dans la soumission à l'ennemi héréditaire” (ibid.: 41); “Elle 
language, which to him/her represents the language of Goethe and Goebbels (ibid.: 46). While studying in Heidelberg in 1930, he/she met Hans-Joachim Friedberg and felt attracted to him. After the beginning of the war, the narrator nevertheless ends all contact: "Il était allemand, j'aimais ma patrie, nous étions en guerre. Il était l'ennemi." (ibid.: 25).

The Gestapo orders the narrator to work as a translator and he/she immediately agrees. It is not until years later that he/she asks him/herself: "Avais-je le choix de refuser? Je n'ai pas osé poser la question" (ibid.: 50). $\mathrm{He} / \mathrm{she}$ felt embarrassed in front of the neighbors for serving the Gestapo ("J'avais honte de servir la Gestapo", ibid.: 52f.) and claims that he/she was forced to do so. But later he/she has to honestly admit: "Je dis que je n'avais pas eu le choix [...]. C'était faux, le commandant n'avait brandi aucune menace." (ibid.: 52). However, to be fair, one has to acknowledge that being summoned by the Gestapo is already frightening if one considers that most of those summoned don't return.

$\mathrm{He} / \mathrm{she}$ ignores the things that he/she sees and hears at the Gestapo headquarters ("Rien vu rien entendu", ibid.: 59). But he/she knows exactly what is happening in the building, because he/she witnesses the torture, murder and deportation of Jews on a daily basis - even though he/she doesn't want to see anything and hides in order not to be confronted with a former Jewish neighbor. ${ }^{34}$

On the one hand, the narrator works for the Gestapo, while on the other hand he/she secretly gives shelter to a Jew in his/her small cellar and hence saves him from being deported. Nevertheless, the reason for this behavior is not to be found in his/her noble convictions, but in him/her feeling sexually attracted to Herman. The narrator hides Herman in the cellar, in the same manner as his/her forbidden books. He/she clearly shows sadistic traits by giving Herman women's panties, not emptying his chamber pot and by sometimes making him wait for his food. ${ }^{35}$ On the one side, the narrator loves

adorait se faire pénétrer par l'ennemi, alors elle le criait. Elle était à l'image de son pays: offerte." (ibid.: 12).

34 "Les personnes convoquées pénétraient dans le bâtiment par la grande porte, elles en ressortaient souvent par celle de derrière, dans un camion bâché destination inconnue" (ibid.: 48); "Je blêmissais, les Allemands poursuivaient leur va-et-vient sous mes yeux comme si de rien n'était, comme si l'on ne massacrait pas des hommes et des femmes, souvent à peine sortis de l'enfance, à l'étage au-dessous. Les Juifs, les Tsiganes (ils étaient moins nombreux), disparaissaient au bout de mon couloir, rassemblés dans une pièce sans fenêtre qui avait été le bureau du caissier de la banque." (ibid.: 56).

${ }^{35} \mathrm{He} / \mathrm{she}$ gives Herman a pair of men's and women's panties in order to humiliate him. This passage is dominated by the semantic field of humiliation and subjugation: "J'aimais imaginer Herman vêtu alternativement en homme et en femme sous son pantalon, c'était un discret moyen de l'humilier, la guerre avait bon dos, mais je voulais garder un certain ascendant sur lui, faciliter sa vie mais pas trop, comme un canari en cage dont on fait mine d'oublier de changer l'eau juste pour qu'il ne puisse pas faire sa toilette comme il faut. J'aurais pu faire bien pire, car il était à ma merci. [...] Je l'avais capturé, [...] les circonstances se chargeaient de le 
German-speaking authors such as Thomas Mann, Heinrich Heine and Hermann Hesse - even though they have been banned by the Nazis. ${ }^{36} \mathrm{He} / \mathrm{she}$ loves and desires Herman the Jew and thus begins to show interest in Yiddish and study the language. On the other hand, he/she often utters anti-Semitic prejudices and accepts the Nazis' Race Laws without remorse. ${ }^{37}$

Already during the war, people don't speak about the arrests, murders and deportations, at least not outside their close family ("En ces temps, les gens qui se connaissaient à peine évitaient d'aborder le sujet", ibid.: 86). They tell the children that a man from the neighborhood lost his arm in a car accident even though he actually lost it while fighting against the Germans in 1940 (ibd.: 97f.). After the war, these incidents are subject to a collective pacte de silence. That especially holds true for the deportations of Jews. This victim group is personified by the neighbor Madame Bloch, who owns a sewing shop: "J'ai souvent repensé à madame Bloch. Elle n'a pas refait surface, évanouie. Après la guerre, plus personne n'en a parlé." (ibid.: 58). The narrator's description of the Shoah is euphemistic because he uses expressions such as "faire surface" or "évanouie". He/she witnessed Mme Bloch's arrest by the Gestapo and therefore he/she knows that the woman was either directly murdered or tortured and deported, just like all the others. The narrator cynically trivializes the period of occupation as an inevitable destiny: "Les hommes passent. Ils courent vers leur destin. [...] Il y a toujours eu des guerres, des injustices, des victimes et des bourreaux." (ibid.: 59f.). ${ }^{38}$

Shortly before the liberation of France, the narrator murders Volker, the SS-officer, and forces Herman to bury him in the hiding-place. He/she allows the Jew to wear the SS-uniform and flee. However, Herman is then mistaken for a member of the SS and is assassinated by the Résistance. ${ }^{39}$ After the war,

maintenir sous ma croupe." (ibid.: 68). The narrator doesn't consider the point that he used similar methods to those of the German occupying forces - even though he/she didn't exert physical violence. To him/her, Herman is not a human being but an object or an animal (canari), at his/her free disposal.

36 “Bien que je n'aie pris aucune part dans la lutte contre l'occupant, mon esprit ne s'intéressait qu'aux recalés de la morale nationale-socialiste" (ibid.: 28) - The narrator arrogantly states: "J'avais tout lu, Lessing, Goethe, Schiller et Kleist, Kant, Nietzsche, Hölderlin, les frère Grimm, Schelling, Brentano, von Arnim, von Chamisso, Hoffmann, Heine, Büchner, Lou AndréasSalomé, Schnitzler, Hoffmannsthal, Rilke, Werfel, Remarque, von Horvath, Jünger, Musil, Hesse, Wassermann, Zweig, Kästner, Benn, Brecht et j'en passe. Ma bibliothèque était l'une des plus belles de la ville." (ibid.: 21).

37 "Le statut des Juifs ne nous a pas touches" (ibid.: 79), "l'inquiétante étrangeté de ces Juifs" (ibid.: 88), "ces Juifs m'agaçaient avec leur écriture secrète" (ibid.: 90), "les Juifs avaient tué le Christ" (ibid.: 122).

${ }^{38}$ The narrator makes another cynical comment, saying that a positive side-effect of Volker's murder is that it spared his children in Germany from an intense feeling of guilt (ibid.: 145), because they don't know what their father has done in France.

39 Thus, the title of the novel is ambiguous: 'Love without resistance' can point to limitless, unconditional love. It can also mean that giving Herman a hiding place was not an act of 
his/her attempts to get Herman recognized as "mort pour la France" fail (ibid.: 153). It is not until years after the war that the narrator feels guilty for not having prevented the suicide of his/her partner Claude: “C'est plus tard qu'est montée cette sensation désagréable, la culpabilité, qui ne vous lâche plus guère une fois qu'elle s'est saisie de vous." (ibid.: 73). The narrator is haunted by the memory of Madame Bloch and tries to track her after the war. But he/she cannot even find her in the list of names at the Mémorial de la deportation des Juifs de France. In a manner similar to that of the narrator of Dora Bruder, this narrator isn't able to fill the gap and mend the absence.

The novel illustrates the difficulty of drawing a clear line between resistance and collaboration and shows how broad the gray zone that lies in between can be. Throughout the novel, the narrator continuously reflects upon this problematic categorization. He/she wonders "Qu'avais-je fait moi-même pour m'opposer à l'occupant?" (ibid.: 42) or states "Je ne songeais pas que je pouvais contribuer de la sorte à la lutte contre l'occupant" (ibid.: 45). He/she describes his/her sister Anne as being "du côté des vaincu" after the war, and considers him-/herself to belong "vaguement du côté des victimes, quoique" (ibid.: 30). However, the expressions "vaguement" and "quoique" raise doubts about the narrator being part of the victim group. Concerning the sister Anne, the reader will probably come to a slightly milder conclusion than the narrator: Apart from being a perpetrator, she can also be seen as a victim since she is a femme tondue and is widowed twice.

In a metatextual passage, the novel alludes to the myth of France résistante, as the narrator comments on the post-war era: "C'était une époque où l'on croyait voir en noir et blanc mais on n'y voyait rien, que du gris, une nuit où tous les chiens sont gris." (ibid.: 128f.). Nobody wants to hear the story of the Jew Herman, who was shot by the Résistance as he fled in an SS-uniform: "Ce n'est qu'aprés la Libération que j'ai raconté toute l'histoire, et encore, ce n'était pas simple, car le pays n'acceptait qu'une vérité, celle des héros, des vainqueurs, des résistants de la première heure qui n'ont jamais eu autant de partisans qu'en 1945." (ibid.: 154). The narrator's father is described as "le grand absent de cette guerre" (ibid.: 30). This can be interpreted as a portrait of the culture of memory: The prisoners of war and the forced laborers are two victim groups that were excluded from collective memory under De Gaulle.

In conclusion, I would like to sum up: Henry Rousso employs a metaphor to characterize the French politics of memory of the early 1970s (le miroir brisé). He uses it to describe how the suppressed elements return during those years,

resistance but rather selfish. Shortly after hiding the Jew in the little cellar, the narrator believes to have engaged in resistance: "Je commençais la guerre et c'était bon. Je résistais, je sauvais un homme" (ibid.: 64). However, he/she later admits that he/she wouldn't have rescued an old and ugly rabbi (ibid.: 127). The title can also mean that the plan was made without taking the Résistance into account, who killed Herman (that is, the only person whom the narrator truly has feelings for). 
ending the myths about the period of occupation. Within literature, the mirror is also an ancient topos, such as in the myth of Narcissus, Stendhal's mirrormetaphor for the novel or the importance of the mirror in psychoanalysis. This mirror-metaphor appears in key scenes of La cliente and Un amour sans résistance: In Assouline's novel, Madame Armand wants to commit suicide by crashing into the mirror. This can mean that she reflects on her own behavior during the German occupation of France and that the feelings of guilt return to her for having betrayed the Jewish Fechner family. By plunging into the mirror, Mme Armand, who finds herself in an identity crisis, wants to erase herself as well as the mirror, which symbolizes these myths. The literary character represents France's confrontation with its own suppressed past and by looking into the mirror, she metaphorically reaches self-awareness.

In Rozier's novel, the mirror is the only witness of the narrator hiding Herman the Jew in his/her cellar. The mirror appears in another key scene: The narrator's mother realizes that her son/daughter murdered the SS-officer in the moment she sees the mirror's reflection of the SS-helmet lying on the wardrobe. ${ }^{40}$ On a meta-level, this can signify the following: What happened in the past can only be understood in a mediated manner. Rozier shows that the perceived image of the past can never be exact and unambiguous, but instead it is subjective and often distorted. Returning to Stendhal's mirror-metaphor, literature itself is the mirror through which we can look into the past after the last witnesses have died. Concerning the memory of the years 1940-44, the mirror-metaphor reveals how historiography and literature overlap each other: Rousso uses a literary metaphor while the literary texts take up his theory of the different phases of French politics of memory.

Both Assouline's and Rozier's novels discuss the femmes tondues. After the liberation, Madame Armand in La cliente and Anne, the narrator's sister in Un amour sans résistance, are both insulted by being called collaborators, they are harassed and Anne is even raped by a neighbor. These novels show that men use women as scapegoats, refusing to admit their own collaboration with the enemy. ${ }^{41}$

The novels suggest that speaking about the past should have more nuance than the public (Gaullist and Communist) discourse about the années noires. Modiano uses the ambiguity of the "blanc", which can describe a gap or a blank space. The "blancs" symbolize the amnesia of post-war society and the actual

40 "J'ai ramené Herman à la maison, ma mère était en courses, ma sœur déshonorait à peine la famille au premier étage, seule la grande glace de l'entrée nous a vus passer mais les miroirs n'ont pas de mémoire, les secrets glissent à leur surface sans laisser de trace." (Rozier 2003: 64); "elle a vu la casquette de Volker sur le buffet de l'entrée à côté du grand plat en faïence de sa grand-mère, une double casquette même, SS et amant de sa fille: elle se reflétait dans le miroir." (ibid.: 140).

${ }^{41}$ During the post-war period, in many regions women's heads are shorn in an act of selfjustice and political 'cleansing', which is supposed to brand them guilty. Cf. Gugglberger 2005. 
impossibility to fully reconstruct the past. Considering the Shoah, the gap left by the murdered victims cannot be filled any more. The only possibility is to point to the traces of the dead and by doing so, to maintain their memory. Literature plays an important part in this context. Assouline uses the metaphor of "le gris" as a central element in his novel: The years of occupation are not clear, they are rather characterized by "ambiguité et compromis" and "la couleur du flou" (Assouline 1998: 60). The words that Rozier's narrator uses to speak about Madame Bloch show attempts - during the war and afterwards to conceal the deportations of Jews with euphemisms. However, this also implies that nobody can escape his or her feelings of guilt and that the suppressed past will eventually return. Once again, literature and historiography meet.

The obsessive focus on the years 1940-44, as diagnosed by Rousso, is present in all three novels: The narrators in Dora Bruder, La cliente and Un amour sans résistance are truly obsessed with the past. All three of them have to acknowledge that the endeavor to fully reconstruct the past or find a historic 'truth' is doomed to fail. The narrator of La cliente even causes immense damage with his naïve self-righteousness. Nevertheless, the narrators' obsession can also be considered a result of the witnesses' silence and suppression. Seen this way, all three novels implicitly call for a cross-generational dialogue without premature accusations and one that doesn't adhere to the myths of the post-war period. ${ }^{42}$

\section{BIBLIOGRAPHY}

AlbERSMEIER, F.-J. (1995), “Erinnern versus Verdrängen und Vergessen: Zur Aufarbeitung der Kollaboration und Résistance-Problematik im französischen Film (1945-1993)", in Paris sous l'Occupation. Paris unter deutscher Besatzung, Drost, W./Leroy, G./Magnou, J./Seibert, P. (eds.), Heidelberg, Winter, 166-177.

Assouline, P. (1998), La cliente, Paris, Gallimard.

AzÉMA, J.-P. (ed.) (1992), Le régime de Vichy et les Français, Paris, Fayard.

AzÉMA, J.-P. and BÉDARIDA, F. (eds.) (2000), La France des années noires, 2 vols, Paris, Seuil.

BARUCH, M.O. (1996), Le régime de Vichy 1940-1944, Paris, Découverte.

BERTIN, C. (1994), Femmes sous l'occupation, Paris, Stock.

BÖHM, R. (2009), “Topographien der Erinnerung im Werk Patrick Modianos”, in Europäische Erinnerungsräume, Buchinger, K., Gantet, C. and Vogel, J. (eds.), Frankfurt and New York, Campus, 103-116.

Burrin, P. (1992), "Vichy", in Les lieux de mémoire. Vol. III. Les Frances. Conflits et partages, Nora, P. (ed.), Paris, Gallimard, 320-345.

CHIRAC, M. J., Allocution de M. Jacques, Président de la République, prononcée lors des cérémonies commémorant la grande rafle des 16 et 17 juillet 1942 [online]. [Retrieved

\footnotetext{
${ }^{42}$ I would like to thank Jenny Augustin for the English translation.
} 
on March 1, 2018]. Available at: <http://www.jacqueschirac-asso.fr/les-grandsdiscours-de-jacques-chirac/?post_id=2326>.

ChIMENÈs, M. (2001), La vie musicale sous Vichy, Bruxelles, Complexe.

CLÉMENT, J.-L. (1999), Les évêques au temps de Vichy : loyalisme sans inféodation; les relations entre l'Eglise et l'Etat de 1940 à 1944, Paris, Beauchesne.

COINTET, M. (ed.) (2000), Dictionnaire historique de la France sous l'Occupation, Paris, Tallandier.

CONE, M. (1992), Artists under Vichy, Princeton, Princeton University Press.

COSNARD, D. (2015), "A Paris, une promenade Dora-Bruder en mémoire des victimes du nazisme", Le Monde [online]. June 1, 2015 [Retrieved on March 9, 2018]. Available at: <http://www.lemonde.fr/culture/article/2015/06/01/a-paris-unepromenade-dora-bruder-en-memoire-des-victimes-dunazisme_4644628_3246.html>.

DARD, O., DuMAS, J.-C. and MARCOT, F. (eds.) (2000), L'Occupation, l'Etat français et les entreprises, Paris, ADHE.

FELBECK, C. (2008), Erinnerungsspiele. Memoriale Vermittlung des Zweiten Weltkriegs im französischsprachigen Gegenwartsdrama, Tübingen, Narr.

GALSTER, I. (2001), Sartre, Vichy et les intellectuels, Paris, Harmattan.

GERHARDI, G. (1995), “Topographie et Histoire : Paris et l'Occupation dans l'œuvre de Patrick Modiano", in Paris sous l'occupation. Paris unter deutscher Besatzung, Drost, W., Leroy, G., Magnou, J. and Seibert, P. (eds.), Heidelberg, Winter, 114-121.

GRIMBERT, P. (2004), Un secret, Paris, Grasset.

GugGLberger, M. (2005), “Den Feind lieben. Geschorene Frauen in Frankreich 194445", in Liebe und Widerstand. Ambivalenzen historischer Geschlechterbeziehungen, Bauer, I. (ed.), Köln et al., Böhlau, 362-375.

HAMMERSCHMIDT, P. (2014), "Deckname Adler". Klaus Barbie und die westlichen Geheimdienste, Frankfurt a. M., Fischer.

HAUSMANN, F.-R. (2005), "Demokratie und Literatur. Das Beispiel der literarischen Kollaboration mit dem Nationalsozialismus", Zeitschrift für Literaturgeschichte, vol. 29 , no. 1/2., 109-128.

HOFFMAN, S. (1968), "Collaborationism in France during World War II", Journal of Modern History, 40, no. 3, 375-395.

JÄCKEL, E. (1966), Frankreich in Hitlers Europa. Die deutsche Frankreichpolitik im 2. Weltkrieg, Stuttgart, DVA.

JungIUS, M. (2008), Der verwaltete Raum. Die 'Arisierung' der Wirtschaft in Frankreich in den Jahren 1940 bis 1944, Ostfildern, Thorbecke.

KlaRSFELD, S. (1978), Le mémorial de la déportation des Juifs de France, Paris, Klarsfeld.

KLARSFELD, S. (1989), Vichy - Auschwitz: die Zusammenarbeit der deutschen und französischen Behörden bei der 'Endlösung der Judenfrage' in Frankreich, Nördlingen, Greno (Original title (1983/1985): Vichy - Auschwitz: le role de Vichy dans la solution finale de la question juive en France, Paris, Fayard).

KOHUT, K. (ed.) (1982), Literatur der Résistance und Kollaboration in Frankreich, Vol. I and II, Wiesbaden, Narr.

KOHUT, K. (ed.) (1984), Literatur der Résistance und Kollaboration in Frankreich, Vol. III, Wiesbaden, Narr.

LAGROU, P. (2002), "Frankreich", in Verbrechen erinnern. Die Auseinandersetzung mit Holocaust und Völkermord, Knigge, V./Frei, N. (eds.), München, Beck, 163-175. 
LABORIE, P. (2001), L'opinion française sous Vichy : les Français et la crise d'identité nationale 1936-1944, Paris, Seuil.

Les FILS ET FILlES DES DEPORTES JUIFS DE FRANCE and MAIRIE DE PARIS. Les 11400 enfants Juifs déportés de France [online]. March 2007 [Retrieved on March 9, 2018]. Available at:

$<$ https://www.google.de/url?sa=t\&rct=j\&q=\&esrc=s\&source=web\&cd=10\&ved=0a hUKEwjt-p-

ms9_ZAhUJShQKHYZTDBkQFghwMAk\&url=http\%3A\%2F\%2Fwww.enseignerhistoire-

shoah.org\%2FgetMedia.aspx\%3FID\%3D205\%26D\%3Dattachment\&usg=AOvVa w1VE0oyH9UdHMsa5EOPnbp8>.

LE RESEAU MODIANO. Modiano-Klarsfeld, une correspondence autour de Dora Bruder [online]. January 28, 2012 [Retrieved on March 9, 2018]. Available at: $<$ http://lereseaumodiano.blogspot.de/2012/01/modiano-klarsfeld-unecorrespondance.html>.

LEVY, M. (2007), Un secret, Paris, Laffont.

MARCot, F., LEROUX, B. and LeVISSE-TOuzÉ, C. (eds.) (2006), Dictionnaire historique de la Résistance, Paris, Laffont.

MARRUS, M.R. and PAXTON, R.O. (1990 [1981]), Vichy et les juifs, Paris, Calmann-Lévy.

MARTENS, S. (ed.) (2000), Frankreich und Deutschland im Krieg: (November 1942 - Herbst 1944); Okkupation, Kollaboration, Resistance, Bonn, Bouvier.

MARTENS, S. (1992), „'Drôle de Guerre' - Occupation - Épuration. Frankreich im Zweiten Weltkrieg“" Neue politische Literatur (NPL) XXXVII, no. 2, 185-213.

MEYER, A. (2000), Die deutsche Besatzung in Frankreich 1940-1944. Widerstandsbekämpfung und Judenverfolgung, Darmstadt, WBG.

MODIANO, P. (1999 [1997]), Dora Bruder, Paris, Gallimard.

MÜLLER, E. and RUOFF, A. (2007), Histoire noire. Geschichtsschreibung im französischen Kriminalroman nach 1968, Bielefeld, Transcript.

NESTMEYER, R. (2014), Alles Mythos. 16 populäre Irrtümer über Frankreich, Darmstadt, WBG.

OPHÜLs, M. (1988), Hôtel Terminus. The Life and Times of Klaus Barbie, USA, Memory Pictures Company.

Paris. Inauguration du Monument à la mémoire des enfants juifs [online]. October 18, 2017 [Retrieved on March 9, 2018]. Available at: $<$ https://www.paris.fr/actualites/inauguration-du-monument-a-la-memoire-desenfants-juifs-5180>.

PAXTON, R.O. (1972), Vichy France: old guard and new order, 1940-1944, New York, A. Knopf.

RAGACHE, G. and J.-R. (1988), La vie quotidienne des écrivains et des artistes sous l'Occupation 1940-1944, Paris, Hachette.

RANDA, P. (1997), Dictionnaire commenté de la collaboration française, Paris, Picollec.

Rousso, H. and CONAN, É. (2013 [1994]), Vichy, un passé qui ne passe pas, Nouvelle édition mise à jour, Paris, Fayard.

Rousso, H. (21990), Le syndrome de Vichy : de 1944 à nos jours, Paris, Ed. du Seuil.

Rousso, H. (2003), Les années noires. Vivre sous l'Occupation, Paris, Gallimard. 
RoussO, H. (2004), "Frankreich. Vom nationalen Vergessen zur kollektiven Wiedergutmachung", in Mythen der Nationen. 1945 - Arena der Erinnerungen, Flacke, M. (ed.), vol. I, Mainz, Philipp von Zabern, 227-248.

RoussO, H. (2002), "Frankreich", in Verbrechen erinnern. Die Auseinandersetzung mit Holocaust und Völkermord, Knigge, V./Frei, N. (eds.), München, Beck, 253-261.

Rousso, H. (1984), Pétain et la fin de la collaboration : Sigmaringen 1944-45, Paris, Complexe.

Rousso, H. (1987), Le syndrome de Vichy (1944-87), Paris, Seuil.

Rousso, H. (2001), Vichy : l'événement, la mémoire, l'histoire, Paris, Gallimard.

ROZIER, G. (2003), Un amour sans résistance, Paris, Denoël.

SAPIRO, G. (1999), La guerre des écrivains. 1940-1953, Paris, Fayard.

SCHUTZ, S. (2000), „'Une sale histoire'. Die unbewältigte Occupation bei Patrick Modiano", in Frankreich und Deutschland im Krieg (November 1942 - Herbst 1944). Okkupation, Kollaboration, Résistance, Martens, S. and Vaïsse, M. (eds.), Bonn, Bouvier, 873-897.

SEGLER-MEßNER, S. (2007), "Die Résistance als nationaler Gründungsmythos und die Perspektive der résistants", in Unausweichlichkeit des Mythos. Mythopoiesis in der europäischen Romania nach 1945, Jünke, C. and Schwarze, M. (eds.), München, Meidenbauer, 183-200.

UMBREIT, H. (1968), Der Militärbefehlshaber in Frankreich 1940-1944, Boppard a.Rh., Boldt.

WIEGEL, W. (2007), "Résistance in Frankreichs Schulen. Môquets Abschiedsbrief”, FAZ [online]. October 21, 2007 [Retrieved on March 9, 2018]. Available at: $<$ http://www.faz.net/aktuell/politik/moquets-abschiedsbrief-resistance-infrankreichs-schulen-1485787.html>.

WieviORKA, O. (1996), "France. A Fragile Consensus”, in Anpassung, Kollaboration, Widerstand. Kollektive Reaktionen auf die Okkupation, Benz, W., Houwink ten Cate, J. and Otto, G. (eds.), Berlin, Metropol, 117-129.

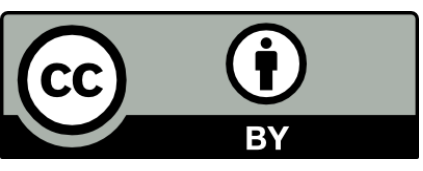

Llevat que s'hi indiqui el contrari, els continguts d'aquesta revista estan subjectes a la llicència de Creative Commons: Reconeixement 3.0 Espanya. 